\title{
MORPHOMETRIC CHARACTERISTICS OF THE LONGITUDINAL PARAMETERS OF THE MIDDLE CRANIAL FOSSA OF ADULTS DEPENDING ON EXTREME TYPE OF SKULLS STRUCTURE
}

\author{
Iryna Chekanova \\ Postgraduate Student at the Department of Human Anatomy, \\ Kharkiv National Medical University, Ukraine \\ e-mail: irynachekanova@ukr.net, orcid.org/0000-0001-6986-258X
}

\begin{abstract}
Summary
Surgical accesses through the middle cranial fossa (MCF) and their variations require the surgeons a detailed understanding of a complex anatomy of this site of the inner base of the skull (IBS) and an individual anatomical variability of the anatomical landmarks often used in their medical practice. The aim of this study is to establish individual anatomical variability of the longitudinal dimensions of MCF of mature age human. The research was carried out by studying 50 craniotomograms and 50 bone preparations of mature age human skulls with their further subdivision to extreme types of skulls groups. The examinations of the main longitudinal parameters were done for detailed MCF craniometry, namely: MCF lateral cranial length, MCF general length, MCF medial areas length. It was determined that all longitudinal dimensions increase from brachicephales to dolichocephales. This is due to the fact that for brachicrans (round-headedness) short form of the skull is inherent, for dolichocrans (narrow-headedness) - long and for mesocrans (moderate-headedness) average head size is inherent. According to the received data, MCF longitudinal parameters of mature age human regardless of the extreme types of the skull structure have the tendency to increase from medial sections of the investigated area to lateral. The results of this study substantially complete the existing information about the individual anatomical variability of MCF of mature age human and also make it possible to deeply use this data in practical medicine and for further research in morphology and in craniology in details.
\end{abstract}

Keywords: individual anatomical variability, adulthood, morphometry, middle cranial fossa.

\section{DOI https://doi.org/10.23856/4333}

Interrelation between publications and planned research works. This work is carried out in accordance with the thematic plan of scientific research of Kharkiv National Medical University, within the topics of the Department of Anatomy "Individual anatomical variability of craniotopographic features and spatial relationships of human head areas in postembryonic period of ontogenesis", number of state registration is $0118 \mathrm{U} 000954$.

\section{Introduction}

For many years, the study of skull structure features especially from the point of view of individual anatomical variability, remained relevant. (Bekov, 1998; Vovk, 2012; O.Yu. Vovk et al., 2016; Yu.N. Vovk et al., 2016). Surgical accesses through the middle cranial fossa (MCF) and their variations require the surgeons a detailed understanding of a complex anatomy of this site of the inner base of the skull (IBS) and an individual anatomical variability of the anatomical landmarks often used in their medical practice. (Altuna et al., 2017; Kizilkanat et al., 2017; 
Maina et al., 2007). Thus, more detailing of the structure, forms and size of MCF, depending on the extreme types of skulls will contribute to the development of low-invasive neurosurgery, otolaryngology, etc. (Eddelman et al., 2019; Mahanbaev et al., 2013; Trosh et al., 2002; Yu.N. Vovk et al., 2016).

The aim of this study is to establish individual anatomical variability of the longitudinal dimensions of MCF of mature age human.

\section{Materials and methods of the study}

The research was carried out by studying 50 craniotomograms and 50 bone preparations of mature age human skulls with their further subdivision to extreme types of skulls groups.

Craniometric study of MCF on CT images of mature age humans was carried out using Anatomage Table anatomy visualization system with Launching Table 6.0 Application setting. Measurement of linear parameters of MCF on bone preparations of the human skull was carried out according to standard craniological technique using a generally accepted set of measuring instruments.

The examinations of the main longitudinal parameters were done for detailed MCF craniometry (fig. 1), namely:

$\mathrm{L}_{1}-\mathrm{MCF}$ lateral cranial length, measured from the most protruding point of small wings of the wedge-shaped bone to the opposite point of the upper edge of the stony part of the temporal bone;

$\mathrm{L}_{2}$ - MCF general length, determined from the arc increase of the anterior surface of the stony part of temporal bone to the opposite point of small wings of the wedge-shaped bone;

$\mathrm{L}_{3}$ - MCF medial areas length, calculated from the lateral edge of the opening of the visual channel to the top of the stony part of the temporal bone.
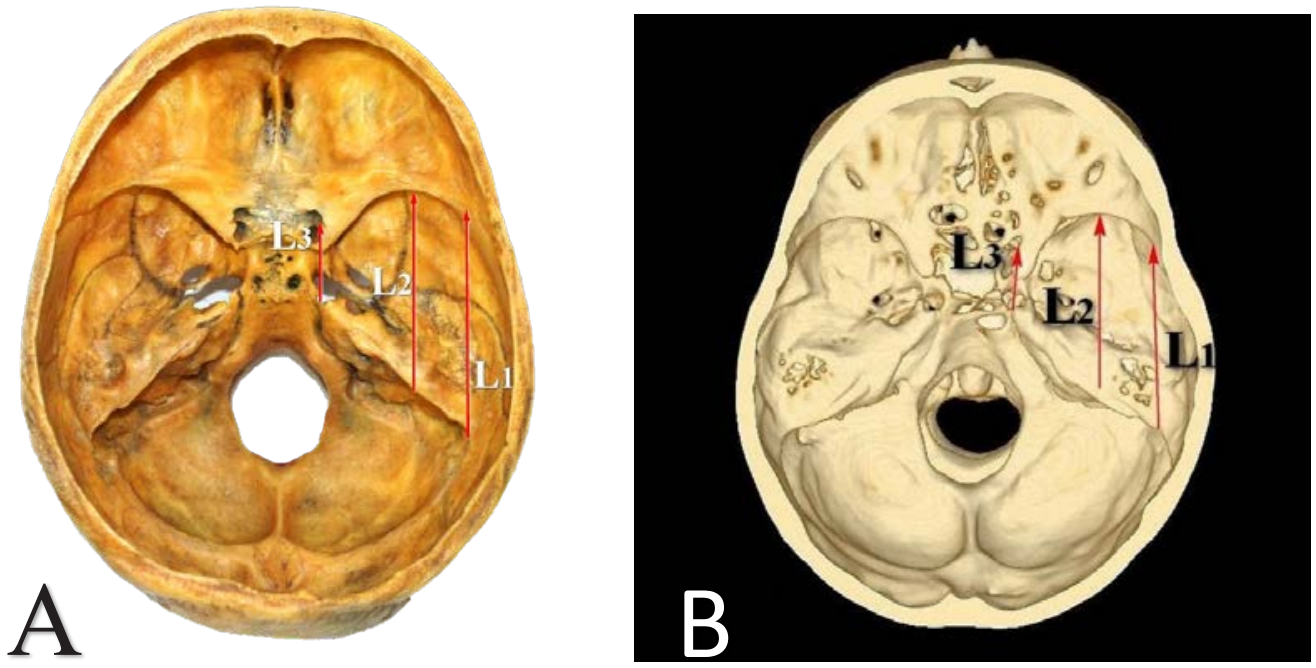

Fig. 1. Determination of MCF of mature age people distances in length: A - on bones preparations; B - of CT images 
In order to distribute the investigated material into groups taking into account the craniotype, a cranial (transverse-longitudinal) index was installed by the formula:

$$
I n d_{\text {skull }}=\frac{\text { the width of the skull }(e u-e u)}{\text { the length of the skull }(g l-o p)} \times 100
$$

In the indicators of this index, less than 74.9 the preparations were attributed to dolichocrans (dolichocephales); 75,0-79,9-mesocrans (mesocephales); 80.0 and more - to brachicrans (brachicefales).

The statistical processing of the received data was carried out using the "SPSS 7.0" applications packets and Excel application from the MS Office XP package with the average arithmetic calculation $(\bar{x})$, mean square deviation $(\sigma)$ and the average error $(\mathrm{m})$ and the Mana-Whitney criterion $(\mathrm{p} \leq 0,05)$.

\section{The results of the study and their discussion}

During the study, the length of the lateral sections of both halves, which is used in determining the transverse-long index of this site of the skull were found (table 1).

Table 1

Variation-statistical indicators of craniometric dimensions of the length of lateral sections of MCF of mature age human (in mm)

\begin{tabular}{|l|l|c|c|c|c|c|}
\hline \multicolumn{2}{|c|}{ Studied signs } & $\min$ & $\max$ & $\overline{\boldsymbol{x}}$ & $\boldsymbol{\sigma}$ & $\mathbf{m}$ \\
\hline \multirow{2}{*}{ Brachicrans } & Left & 59,0 & 79,0 & 68,08 & 5,258 & 0,696 \\
\cline { 2 - 7 } & Right & 60,5 & 79,0 & 68,48 & 5,021 & 0,665 \\
\hline \multirow{2}{*}{ Mesocrans } & Left & 60,5 & 80,0 & 70,84 & 5,526 & 0,993 \\
\cline { 2 - 7 } & Right & 59,7 & 81,0 & 70,75 & 5,606 & 1,007 \\
\hline \multirow{2}{*}{ Dolichocrans } & Left & 66,0 & 83,0 & 74,36 & 5,160 & 1,490 \\
\cline { 2 - 7 } & right & 65,0 & 82,0 & 73,58 & 4,825 & 1,393 \\
\hline
\end{tabular}

According to our data, in people of mature age with a brachiocephalic form of the skull structure the length of MCF lateral sections on the left does not exceed $\bar{x} \pm \sigma=68,08 \pm 5,258 \mathrm{~mm}$ and $\bar{x} \pm \sigma=68,48 \pm 5,021 \mathrm{~mm}$ on the right. In mesocrans the mentioned size is slightly increasing reaching $\bar{x} \pm \sigma=70,84 \pm 5,526 \mathrm{~mm}$ and $\bar{x} \pm \sigma=70,75 \pm 5,606 \mathrm{~mm}$ of the left and right areas of MCF consequently. The parameter $\mathrm{L}_{1}$ reaches maximal meanings in people with dolichocephalic structure and comprises $\bar{x} \pm \sigma=74,36 \pm 5,160 \mathrm{~mm}$ on the left and $\bar{x} \pm \sigma=73,58 \pm 4,825 \mathrm{~mm}$ on the right.

Similarly, the range of individual anatomical variability of the total length of MCF of mature age human is established (table 2).

Thus, from the left half of MCF total longitudinal parameter accounting the craniotype in brachicephales equals $\bar{x} \pm \sigma=53,14 \pm 5,241 \mathrm{~mm}$, in mesocephales it has the meaning $\bar{x} \pm \sigma=$ $=56,17 \pm 4,241 \mathrm{~mm}$ in dolichocrans it comprises $\bar{x} \pm \sigma=56,86 \pm 4,072 \mathrm{~mm}$.

From MCF right side for a given size $\mathrm{L}_{2}$ minimal meanings are typical $\bar{x} \pm \sigma=$ $=53,88 \pm 4,944 \mathrm{~mm}$ in mature age people with brachicranial type of the skull and maximal meanings $\bar{x} \pm \sigma=56,94 \pm 3,763 \mathrm{~mm}$ in male and female of the same age period with dolichocranic type of the skull. In mesocephales total length of MCF has average meanings and comprises $\bar{x} \pm \sigma=55,87 \pm 4,218 \mathrm{~mm}$. 
Table 2

\section{Variation-statistic indices of craniometrics sizes of MCF general length of mature age human (in $\mathrm{mm}$ )}

\begin{tabular}{|l|l|c|c|c|c|c|}
\hline \multicolumn{2}{|l}{ Studied signs } & \multirow{2}{*}{ min } & $\max$ & $\overline{\boldsymbol{x}}$ & $\boldsymbol{\sigma}$ & $\mathbf{m}$ \\
\hline \multirow{2}{*}{ Brachicrans } & Left & 42,9 & 65,0 & $53,14^{*}$ & 5,241 & 0,694 \\
\cline { 2 - 7 } & Right & 42,6 & 65,0 & 53,88 & 4,944 & 0,655 \\
\hline \multirow{2}{*}{ Mesocrans } & Left & 46,8 & 64,0 & 56,17 & 4,241 & 0,762 \\
\cline { 2 - 7 } & Right & 47,3 & 65,0 & $55,87 * *$ & 4,218 & 0,757 \\
\hline \multirow{2}{*}{ Dolichocrans } & Left & 48,4 & 64,0 & $56,86^{* *}$ & 4,072 & 1,176 \\
\cline { 2 - 7 } & Right & 49,2 & 63,9 & $56,94 * *$ & 3,763 & 1,086 \\
\hline
\end{tabular}

The morphometric study of the medial length from MCF both sections of mature age people was carried out (table 3 ).

It was determined that the smallest MCF longitudinal size has a certain range of individual variability, namely: in brachicrania it is $\bar{x} \pm \sigma_{-}=21,99 \pm 2,305 \mathrm{~mm}$ on the left and $\bar{x} \pm \sigma=22,12 \pm 2,462 \mathrm{~mm}$ on the right; in mesocrania $-\bar{x} \pm \sigma=23,70 \pm 2,362 \mathrm{~mm}$ and $\bar{x} \pm \sigma=$ $=23,64 \pm 2,717 \mathrm{~mm}$ consequently; in dolichocrania the mentioned parameter from MCF left part is $\bar{x} \pm \sigma=24,48 \pm 2,591 \mathrm{~mm}$ and from the right port $-\bar{x} \pm \sigma=25,34 \pm 3,033 \mathrm{~mm}$.

Table 3

\section{Variation-statistic indices of craniomentric sizes of MCF medial length of mature age human (in $\mathbf{m m}$ )}

\begin{tabular}{|l|c|c|c|c|c|c|}
\hline \multicolumn{2}{|c|}{ Studied sign } & $\boldsymbol{m i n}$ & $\mathbf{m a x}$ & $\overline{\boldsymbol{x}}$ & $\boldsymbol{\sigma}$ & $\mathbf{m}$ \\
\hline \multirow{2}{*}{ Brachicrans } & Left & 18,0 & 26,0 & 21,99 & 2,305 & 0,320 \\
\cline { 2 - 7 } & Right. & 17,7 & 27,0 & 22,12 & 2,462 & 0,345 \\
\hline \multirow{2}{*}{ Mesocrans } & Left & 18,5 & 28,0 & 23,70 & 2,362 & 0,431 \\
\cline { 2 - 7 } & Right & 18,9 & 29,0 & 23,64 & 2,717 & 0,488 \\
\hline \multirow{2}{*}{ Dolichocrans } & Left & 21,0 & 30,0 & 24,48 & 2,591 & 0,748 \\
\cline { 2 - 7 } & Right & 22,4 & 33,0 & 25,34 & 3,033 & 0,876 \\
\hline
\end{tabular}

Thus it was determined that all longitudinal dimensions increase from brachicephales to dolichocephales (fig. 2, fig. 3). This is due to the fact that for brachicrans (round-headedness) short form of the skull is inherent, for dolichocrans (narrow-headedness) - long and for mesocrans (moderate-headedness) average head size is inherent (Vovk et al., 2019).

According to the received data, MCF longitudinal parameters of mature age human regardless of the extreme types of the skull structure have the tendency to increase from medial sections of the investigated area to lateral (fig. 3).

In the course of the study of MCF linear parameters of mature age human it has been found that longitudinal parameters at different levels of the investigated area have a certain range of individual variability with the smallest values in brachicrans and the largest - in dolichocrans. In humans with mesocranic type of the skull average values of MCF length are determined. Morphometric study also showed the predominance of longitudinal sizes in lateral sections of the studied MCF area with average values of total length and minimal in the medial sections of MCF. 


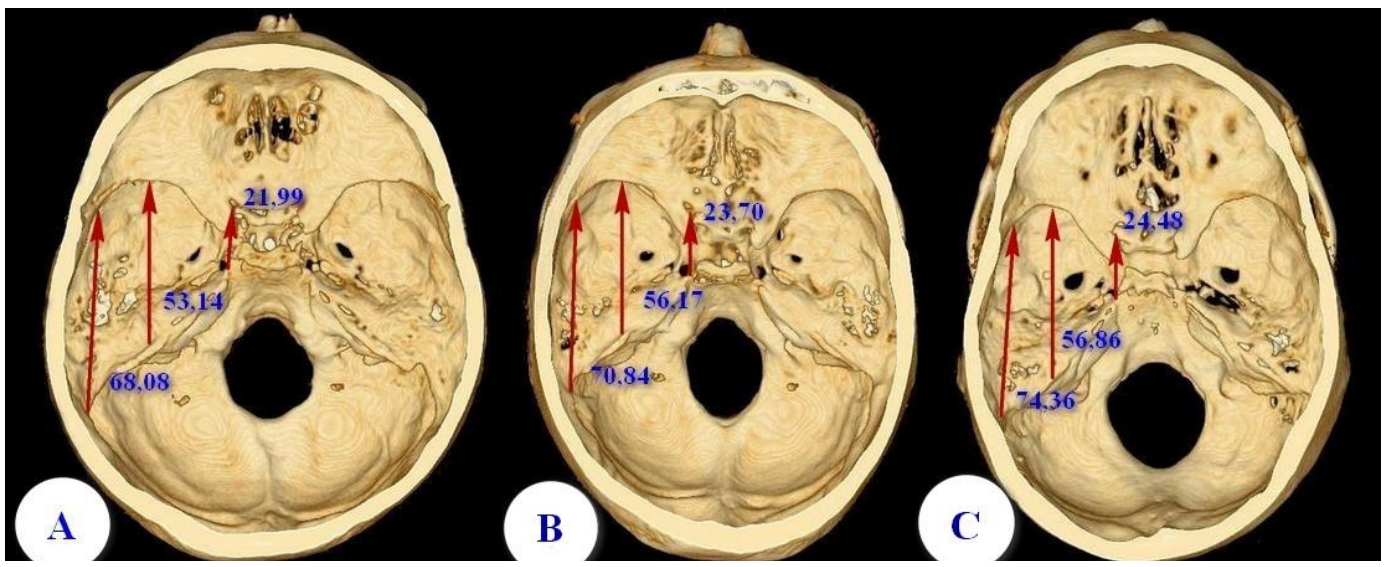

Fig. 2. MCF longitudinal sizes of average meanings on CT images of mature age human depending on extreme types of the skull: A - brachicrans; B - mesocrans;

$\mathrm{C}$ - dolichocrans.

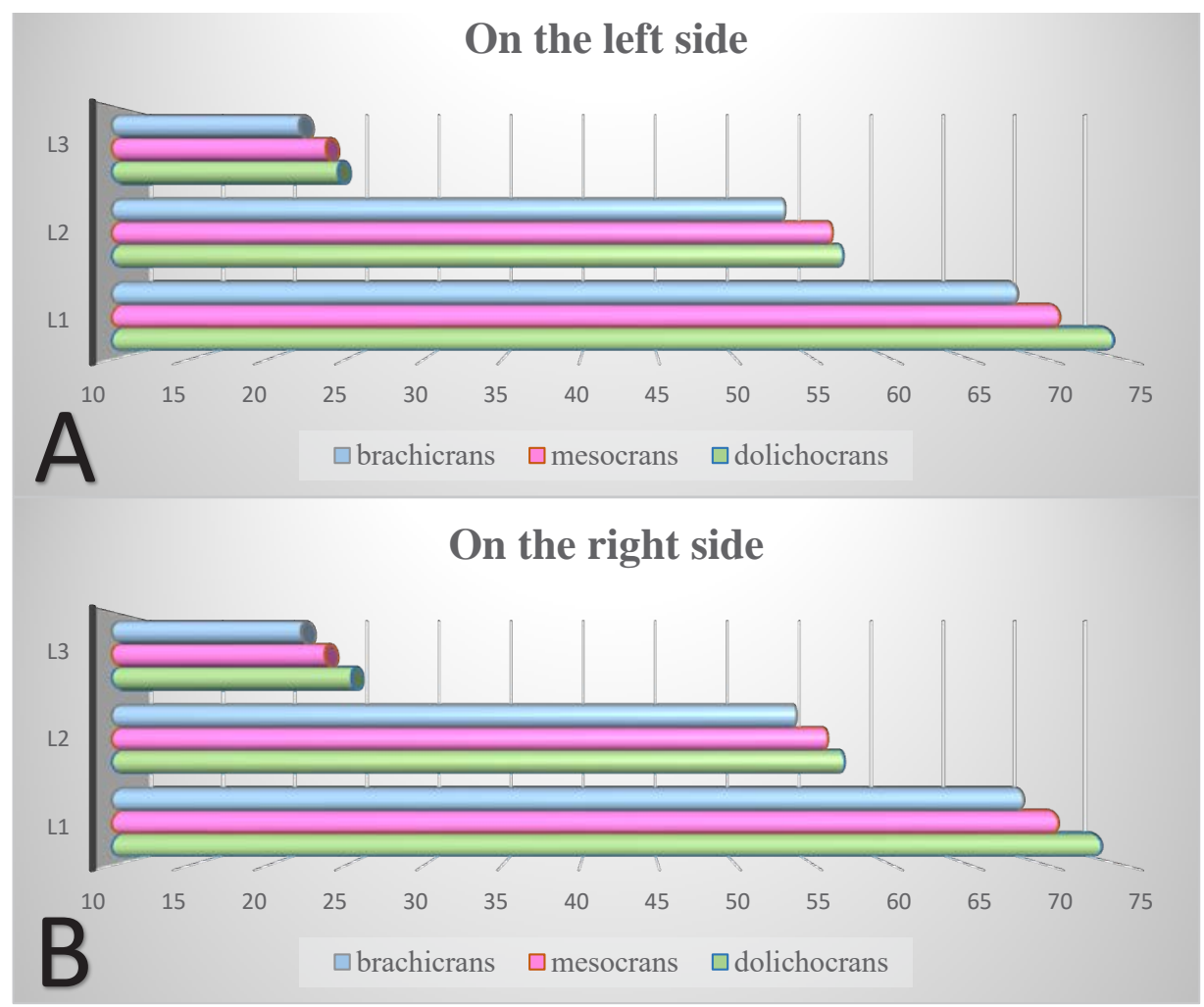

Fig. 3. Range of MCF longitudinal sizes individual variability of mature age human: A - from MCF left section; B - from MCF right section. 


\section{Conclusions}

Prospects for further research. Thus, the results of this study substantially complete the existing information about the individual anatomical variability of MCF of mature age human and also make it possible to deeply use this data in practical medicine and for further research in morphology and in craniology in details.

\section{References}

Altuna, X., Navarro, J. J., García, L., Ugarte, A., \& Thomas, I. (2017). Middle cranial fossa approach for the repair of spontaneous cerebrospinal fluid leaks to the middle ear. Abordaje por fosa media para el cierre de fístulas de líquido cefalorraquídeo espontáneas a oído medio. Acta otorrinolaringologica espanola, 68(2), 86-91. https://doi.org/10.1016/j.otorri.2016.04.002

Bekov D.B. (1998). Individualnaya anatomicheskaya izmenchivost-ee nastoyashee i budushee [Individual anatomical variability - its present and future] Ukr. med. Almanah - Ukrainian Medical Almanac. 2, 14-16. [in Russian].

Eddelman, D. B., Munich, S., Kochanski, R. B., Eggerstedt, M., Kazan, R. P., Moftakhar, R., et al. (2019). Repair of Temporal Bone Defects via the Middle Cranial Fossa Approach: Treatment of 2 Pathologies With 1 Operation. Neurosurgery, 84(6), 1290-1295. https://doi.org/10.1093/ neuros/nyy198

Kizilkanat E.D., Boyan N., Tekdemir I., Soames R., Oguz O. (2017). Surgical importance of the morphometry of the anterior and middle cranial fossae. Neurosurgery Quarterly. 17(1), 60-63. Mahanbaev G.D., Kauynbekova Sh.M., Ahanov G.Zh. (2013). Minimalno innvazivnye dostupy pri hirurgii osnovaniya perednej i srednej cherepnoj yamki [Minimally invasive approaches for surgery of the base of the anterior and middle cranial fossa] Vestnik AGIUV-Bulletin of AGIUV, 1, 25-26. [in Russian].

Maina, R., Ducati, A., \& Lanzino, G. (2007). The middle cranial fossa: morphometric study and surgical considerations. Skull base : official journal of North American Skull Base Society ... [et al.], 17(6), 395-403. https://doi.org/10.1055/s-2007-991117

Trosh R.M., Shamaiev M.I., Kondratiuk V.V., Kvasha M.S. (2002). Infratemporalnyi dostup pry pukhlynakh serednoi cherepnoi yamky (mikrokhirurhichne obgruntuvannia). [Infratemporal access in tumors of the middle cranial fossa (microsurgical rationale)] Ukrainskyi neirokhirurhichnyi zhurnal- Ukrainian Neurosurgical Journal, 4, 35-37. [in Ukrainian].

Vovk O.Yu. (2012). Individualnaya anatomicheskaya izmenchivost mozgovogo otdela golovy i cherepa vzroslogo cheloveka [Individual anatomical variability of the cerebral section of the head and skull of an adult] Ukrayinskij zhurnal klinichnoyi ta laboratornoyi medicini Ukrainian journal of clinical and laboratory medicine, 7(3),80-84. [in Russian].

Vovk O.Yu., Suhonosov R.A. (2016). Individualnaya anatomicheskaya izmenchivost osnovnyh kraniometricheskih pokazatelej u lyudej zrelogo vozrasta [Individual anatomical variability of the main craniometric parameters in people of mature age] Morphologia-Morphology, 10 (3), 71-76. [in Russian].

Vovk Yu.N., Vovk O.Yu. (2016). Perspektivy i novye napravleniya ucheniya ob individualnoj anatomicheskoj izmenchivosti [Prospects and new directions in the study of individual anatomical variability] Visnik problem biologiyi i medicini - Bulletin of problems biology and medicine, 1 (128), 376-379. [in Russian].

Vovk Yu.N., Vovk O.Yu., Ikramov V.B., Shmargalev A.A., Malahov S.S. (2016). Prakticheskoe znachenie individualnoj anatomicheskoj izmenchivosti dlya sovremennoj kraniologii 
[Practical significance of individual anatomical variability for modern craniology] Klinichna anatomiya ta operativna hirurgiya - Clinical anatomy and operative surgery, 15(1), 105-109. [in Russian].

Vovk Yu.M., Vovk O.Yu. (2019). Indyvidualna anatomichna minlyvist ta yii kliniko-morfolohichne znachennia [Individual anatomical variability and its clinical and morphological significance] Kharkiv: FOP Brovin O. V. [in Ukrainian]. 